\title{
AL WAZHIFAH AL 'ĀMMAH \\ (PELAYANAN PUBLIK DALAM LEMBAGA KEUANGAN SYARIAH)
}

\author{
Dicky Maulidhany \\ Pascasarjana Prodi Hukum Ekonomi Syariah \\ Universitas Islam Negeri Sunan Gunung Djati Bandung \\ dickymaulidani@gmail.com
}

\begin{abstract}
This paper discusses the quality of public services from Islamic banking. Quality of service is one of the important things for customers or customers compared to companies engaged in the company. Quality of service can be realized through its employees, among others: honest, humble service and services in accordance with Islam. Some aspects of the quality of this compilation are applied together to build a very good and satisfying quality service, so as to ensure a sizable quality of service in choosing priorities to use services which in this case is to save Islamic financial institutions.
\end{abstract}

Keywords: Quality, paradigm, public service

\begin{abstract}
ABSTRAK
Tulisan ini membahas mengenai kualitas pelayanan publik dari perbankan syariah. Kualitas layanan adalah salah satu hal penting untuk penilaian dari konsumen atau pelanggan terhadap perusahaan yang bergerak di dalamnya. Kwalitas pelayanan dapat terwujud melalui karyawannya antara lain: jujur, Pelayanan rendah hati dan pelayanan yang sesuai dengan Islam. Beberapa aspek kualitas ini ketika diterapkan bersama dapat membangun layanan kualitas yang sangat baik dan memuaskan, sehingga dapat dikatakan bahwa kualitas layanan memiliki pengaruh yang cukup besar dalam menentukan minat nasabah untuk menggunakan pelayanan yang dalam hal ini adalah untuk menyelamatkan Lembaga keuangan syariah .
\end{abstract}

Kata kunci: Kualitas, paradigma, pelayanan publik 


\section{PENDAHULUAN}

Islam adalah ajaran yang komprehensif yaitu suatu ajaran hidup yang mencakup seluruh aspek kehidupan. Islam merupakan sebuah sistem yang bernuansa universal jika dipahami secara utuh dan totalitas dalam pengamalannya. Termasuk sistem ekonomi, sesungguhnya sistem ekonomi dalam islam pun bersifat universal bisa digunakan oleh siapapun, tidak terbatas oleh pemeluknya. Ekonomi merupakan faktor terpenting sebagai penunjang keberlangsungan hidup.

Pertumbuhan perkembangan ekonomi masyarakat secara alami mendorong dibutuhkannya lembaga-lembaga keuangan yang bisa memberikan keuangan dan pembiayaan kepada masyarakat. Selain itu, masyarakat menginginkan adanya sistem pembiayaan tanpa riba yang mendorong lahirnya bank syariah. Bank Syariah merupakan Bank yang menjalankan kegiatan usahanya berdasarkan prinsip-prinsip syariah. Produk bank sangat bergantung dari layanan yang diberikan oleh karyawan bank, maka kwalitas pelayanan sangat menentukan keunggulan produk tersebut. Akan tetapi, pada kenyataanya masih lazim terjadi pelayanan yang kurang prima dari lembaga keuangan syariah tersebut, padahal pelayanan yang prima akan berdampak positif yaitu akan membuat nasabah loyal terhadap bank. Kualitas layanan merupakan faktor penting dalam suatu perusahaan karena kualitas pelayanan konsumen dipandang sebagai filosofi utama oleh para manager di Indonesia.
Bagi perusahaan yang bergerak di bidang jasa perbankan, memuaskan nasabah adalah hal pokok yang tidak boleh diabaikan, dimana kepuasan nasabah merupakan faktor yang sangat strategis dalam memenangkan persaingan, mempertahankan citra perusahaan di masyarakat luas. Kepuasan konsumen ditentukan oleh kualitas produk dan layanan. Perlu diketahui bahwa pelanggan selalu menilai suatu layanan yang diterima dari pada apa yang diharapkan atau yang diinginkan. Berdasarkan uraian di atas, penulis akan memaparkan pelayanan publik dalam Lembaga Keuangan Syariah yakni dalam perbankan syariah.

Pada hakikatnya setiap manusia di dunia ini membutuhkan pelayanan, karena pada dasarnya pelayanan tidak bisa dilepaskan dari kehidupan manusia. Negara merupakan suatu organisasi yang di dalamnya dapat menghubungkan masyarakat dengan pemerintah, maka masyarakat sebagai pemegang kedaulatan menuntut pelayanan publik yang berkualitas dari aparatur pemerintah, karena mereka diangkat untuk melayani masyarakat. Di Indonesia, konsepsi pelayanan administrasi pemerintah seringkali dipergunakan secara bersamaan atau dipakai sebagai sinonim dari kata konsepsi pelayanan perijinan dan pelayanan umum, serta pelayanan publik. Keempat istilah ini dipakai sebagai terjemahan dari publik service. Hal ini dapat dilihat dari dokumen-dokumen pemerintah sebagaimana dipakai oleh 
Kementrian Pendayagunaan Aparatur Negara. ${ }^{1}$

Dalam kajian ini, administrasi pemerintah disejajarkan atau disamakan pengertiannya dan penggunaannya sebagai sinonim dari pelayanan perijinan, yang merupakan terjemahan administrative service. Sedangkan pelayanan umum lebih sesuai jika dipakai untuk menerjemahkan konsep public service. Istilah pelayanan umum ini dapat disejajarkan dengan istilah pelayanan publik.

\section{Definisi Pelayanan Publik}

Pengertian Pelayanan Publik atau the civil service (bahasa Inggris) mempunyai arti sebagai otoritas administrasi untuk melaksanakan kebijakan umum negara dan melayani fasilitas publik melalui sejumlah karyawan yang banyak yang telah dipilih sebagai pejabat publik atau aparatur sipil negara, dan karyawan ini mempunyai sistem yang mengatur posisi mereka dan mengatur urusan pekerjaan mereka di sebagian besar negara di dunia. ${ }^{2}$

Pelayanan publik bisa diartikan sebagai fasilitas layanan yang disediakan untuk masyarakat, baik layanan secara umum maupun khusus. ${ }^{3}$ Sedangkan menurut Lewis dan Gilman menjelaskan bahwa pelayanan publik adalah kepercayaan masyarakat kepada Negaranya. Masyarakat berharap dengan adanya

\footnotetext{
1 Ismet Sulila, Implementasi Dimensi Pelayanan Publik Dalam Konteks Otonomi Daerah, (Yogyakarta: DEEPUBLISH, 2015), hlm. 73-74

2 Muhammad Ali Ustman, Fiqh al Muamalah: Dirasah Muqaranah (Riyadh: Dār al Mirikh, 1986), hlm. 352-390

3 Fakhira Amylia, Jurnal Peayanan Publik Dalam Hukum Administrasi Negara
}

pelayanan publik yang didirikan oleh negara, agar dapat dilakukan dengan jujur dan mengelola penghasilan secara baik, agar bisa dipertanggungjawabkan dihadapan publik. Pelayanan publik yang dilakukan secara adil dan bisa dipertanggungjawabkan dihadapan publik dan bisa mendapatkan kepercayaan publik.

Berdasarkan ketentuan dalam pasal 1 angka 1 Undang-Undang Nomor 25 Tahun 2009 tentang Pelayanan Publik yang mengatur bahwa: Pelayanan publik adalah kegiatan atau rangkaian kegiatan dalam rangka pemenuhan kebutuhan pelayanan sesuai dengan peraturan perundang-undangan bagi setiap warga negara dan penduduk atas barang, jasa, dan/atau pelayanan administratif yang disediakan oleh penyelenggara pelayanan publik. ${ }^{4}$

Keputusan Menteri Pendayagunaan Aparatur Negara No. 63 Tahun 2003 mendefinisikan pelayanan umum sebagai berikut:

Segala bentuk pelayanan yang dilaksanakan oleh instansi Pemerintah di Pusat, di Daerah dan di lingkungan Badan Usaha Milik Negara atau Badan Usaha Milik Daerah bentuk barang atau jasa, baik dalam upaya pemenuhan kebutuhan masyarakat maupun dalam rangka pelaksanaan ketentuan peraturan perundang-undangan (Keputusan MENPAN No. 63/2003).

Mengikuti definisi diatas, pelayanan publik atau melayanan umum dapat didefinisikan sebagai segala bentuk jasa pelayanan, baik dalam bentuk barang

${ }^{4}$ Hadi Tuasikal, Jurnal Membedah Konsep Pelayanan Publik Dan Good Governance Dalam Perspektif Hukum Administrasi, 
publik baupun jasa publik yang pada prinsipnya menjadi tanggungjawab dan dilaksanakan oleh instansi Pemerintah di Pusat, di Daerah, dan Lingkungan Badan Usaha Milik Negara atau Badan Usaha Milik Daerah, dalam rangka pelaksanaan ketentuan peraturan perundangundangan.

\section{Unsur-unsur Pelayanan Publik}

Dalam proses pelayanan publik, ada empat unsur penting yang harus diperhatikan, yakni: ${ }^{5}$

1. Penyedia layanan, yaitu pihak yang dapat memberikan suatu layanan tertentu kepada konsumen, baik berupa layanan dalam bentuk penyediaan dan penyerahan barang (goods) atau jasa-jasa (services).

2. Penerima layanan, yaitu mereka yang disebut sebagai konsumen (costomer) atau customer yang menerima berbagai layanan dari penyedia layanan.

3. Jenis layanan, yaitu layanan yang dapat diberikan oleh penyedia layanan kepada pihak yang membutuhkan layanan.

4. Kepuasan pelanggan, dalam memberikan layanan penyedia layanan harus mengacu pada tujuan utama pelayanan, yaitu kepuasan pelanggan.

5 Adya Barata, Atep, Dasar-Dasar Pelayanan Prima. (Jakarta:PT Elex Media Komputindo, 2004)

\section{Konsepsi Kwalitas Pelayanan}

Pelayanan pada umumnya bisa diartikan sebagai aktifitas seseorang atau sekelompok baik langsung maupun tidak langsung dalam rangka memenuhi kebutuhan pelanggan.

Monir mengatakan bahwa pelayanan adalah proses pemenuhan kebutuhan-kebutuhan melalui aktifitas orang lain secara langsung. ${ }^{6}$ Sedangkan Menteri Pendayagunaan Aparatur Negara (1993), mengemukakan bahwa pelayanan adalah segala bentuk kegiatan pelayanan dalam bentuk barang atau jasa dalam rangka upaya pemenuhan kebutuhan masyarakat.

Pelayanan publik menurut Sinembela adalah sebagai setiap kegiatan yang dilakukan oleh pemerintah terhadap sejumlah manusia yang memiliki setiapkegiatan yang menguntungkan dalam suatu kumpulan atau kesatuan, dan menawarkan kepuasan meskipun hasilnya tidak terikat pada suatu produk secara fisik. ${ }^{7}$ Sementara menurut Montgomery (dalam Pasalong 2007: 132) "The extent to which products meet the requirement of people who use them" jadi satu produk, apakah itu berbentuk barang atau jasa, dikatakan bermutu bagi seseorang kalau produk tersebut dapat memenuhi kebutuhannya. Pada dasarnya pelayanan (service) oleh beberapa penulis mendefinisikan sebagai pelayanan atau perbuatan (deed), satu kinerja (performance) atau

6 Harbani Pasolong, Teori Administrasi Publik, (Bandung: Alfabeta, 2011), 128.

7 Harbani Pasolong, Teori Administrasi Publik, (Bandung: Alfabeta, 2011), 128. 
suatu usaha (effort) menurut Pamudji memberikan pemahaman sebagai berbagai kegiatan pemerintah yang bertujuan untuk kebutuhan masyarakat akan barang dan jasa, ahli lainnya juga menyatakan bahwa produk (barang modal dan barang pakai) sampai pada jasa (jasa pasar dan jasa publik), dan pelayanan sipil keterlibatan pemerintah dalam penyelenggaraan dalam fungsi. Pelayanan semakin berkembang seiring dengan munculnya paham atau pandangan mengenai filsafat Negara. Semenjak dilaksanakannya cita-cita Negara kesejahteraan, maka pemerintah semakin intensif melakukan campur tangan interaksi kekuatan-kekuatan kemasyarakatan dengan tujuan agar setiap warga dapat terjamin kepastian hidup minimalnya. Oleh karena itu secara berangsur-angsur, fungsi awal dari pemerintahan yang bersifat represif (kebijakan dan peradilan) kemudian ditambah dengan fungsi-fungsi yang bersifat melayani. ${ }^{8}$

Aspek-aspek pelayanan publik bertujuan untuk memuaskan masyarakat untuk mencapai tujuan itu maka pelayanan publik antara lain tranparansi, yakni pelayanan yang bersifat terbuka, mudah dan dapat diakses oleh semua pihak yang membutuhkan dan disediakan secara memadai serta mudah dimengerti.

8 Ismet Sulila, Implementasi Dimensi Layanan Publik Dalam Konteks Otonomi Daerah (Deepublish, 2015), 86.

\section{Kualitas Pelayanan}

Kualitas pada dasarnya merupakan kata yang menyandang arti relatif karena bersifat abstrak, kualitas dapat digunakan untuk menilai atau menentukan tingkat penyesuaian suatu hal terhadap persyaratan atau spesifikasinya. Kualitas menurut Fandy Tjiptono adalah 1) kesesuaian dengan persyaratan atau tuntutan, 2) kecocokan pemakaian, 3) perbaikan atau penyempurnaan keberlanjutan, 4) bebas dari kerusakan, 5) pemenuhan kebutuhan pelanggan semenjak awal dan setiap saat, 6) melakukan segala sesuatu secara benar semenjak awal, 7) sesuatu yang bisa membahagiakan pelanggan. ${ }^{9}$

Kasmir mengatakan bahwa pelayanan yang baik adalah kemampuan seseorang dalam memuaskan pelanggan terhadap pelayanannya yang dapat memberikan kepuasan kepada pelanggan dengan standard operasional prosedut yang ditentukan (Pasolong, 2011: 133). Menurut Zethami \& Haywood Farmer mengatakan ada tiga karakteristik utama tentang pelayanan, yaitu: ${ }^{10}$

1. Intangibility bisa diartikan pelayanan pada dasarnya bersifat performance dan hasil pengalaman dan bukan objek. Kebanyakan pelayanan tidak dapat dihitung, diukur, diraba atau dites sebelum disampaikan untuk menjamin kualitas. Berbeda dengan barang yang dihasilkan oleh suatu pabrik

9 Harbani Pasolong, Teori Administrasi Publik, ...132.

${ }^{10}$ Harbani Pasolong, Teori Administrasi Publik,... 133-134.

Jurnal Ilmu Akuntansi dan Bisnis Syariah 
yang dapat dites kualitasnya sebelum disampaikan pada pelanggan.

2. Heterogeinity berarti pemakai jasa atau klien atau pelanggan memiliki kebutuhan yang sangat beragam. Pelanggan dengan pelayanan yang sama mungkin mempunyai prioritas berbeda. Demikian pula performance sering bervariasi dari suatu prosedur ke prosedur lainnya bahkan dari waktu ke waktu.

3. Inseparability, adalah bahwa produksi dan konsumsi suatu pelayanan tidak terpisahkan. Konsekuensinya di dalam industri pelayanan kualitas tidak direkayasa ke dalam produksi di sektor pabrik dan kemudian disampaikan kepada pelanggan. Kualitas terjadi selama interaksi antara klien dan penyedia jasa.

Untuk mengetahui kualitas pelayanan yang dirasakan secara nyata oleh konsumen, ada indikator ukuran kepuasan konsumen yang terletak pada lima dimensi kualitas pelayanan menurut apa yang dikatakan konsumen. Kelima dimensi servqual tersebut: ${ }^{11}$

1. Tangibles: kualitas pelayanan berupa sarana fisik perkantoran, komputerisasi administrasi, ruang tunggu, tempat informasi.

2. Reability: kemampuan dan keandalan untuk menyediakan pelayanan yang terpercaya.

11 Zeithaml, V.A., Parasuraman \& L.L. Berry, Delivering Quality Services, 1990.
3. Responsivess: kesanggupan untuk membantu dan menyediakan pelayanan secara cepat dan tepat, serta tanggap terhadap keinginan konsumen.

4. Assurance: kemampuan dan keramahan serta sopan santun pegawai dalam meyakinkan kepercayaan konsumen.

5. Emphaty: sikap tegas tetapi penuh perhatian dari pegawai terhadap konsumen.

\section{Jenis-Jenis Pelayanan Publik}

Definisi pelayanan publik menurut Kepmen PAN Nomor 25 tahun 2004 adalah segala kegiatan pelayanan yang dilaksanakan oleh penyelenggara pelayanan publik sebagai upaya pemenuhan kebutuhan penerima layanan, maupun dalam rangka pelaksanaan ketentuan peraturan perundang-undangan. Sedangkan Kepmen PAN Nomor 58 Tahun 2002 mengelompokkan tiga jenis pelayanan dari instansi pemerintah serta BUMN atau BUMD. Pengelompokkan jenis pelayanan tersebut didasarkan pada ciri-ciri dan sifat kegiatan serta produk pelayanan yang dihasilkan, yaitu:

1. Jenis Pelayanan Administratif. Yaitu jenis pelayanan yang diberikan oleh unit pelayanan berupa kegiatan pencatatan, penelitian, pengambilan keputusan, dokumentasi, dan kegiatan tata usaha lainnya yang secara keseluruhan menghasilkan produk akhir berupa dokumen. Contoh jenis pelayanan ini misalnya: ser- 
tifikat, izin-izin, rekomendasi, keterangan tertulis, dan lainlainnya. ${ }^{12}$

2. Jenis Pelayanan Barang. Yaitu jenis pelayanan yang diberikan oleh unit pelayanan berupa kegiatan penyediaan dan atau pengolahan bahan berwujud fisik termasuk distribusi dan penyampaiannya kepada konsumen langsung (sebagai unit atau sebagai individual) dalam satu sistem. Secara keseluruhan kegiatan tersebut menghasilkan produk akhir berwujud benda (berwujud fisik) atau yang dianggap benda yang memberikan nilai tambah secara langsung bagi penerimanya. Contoh jenis pelayanan ini adalah: pelayanan listrik, pelayanan air bersih, dan pelayanan telpon. ${ }^{13}$

3. Jenis Pelayanan Jasa. Yaitu jenis pelayanan yang diberikan oleh unit pelayanan berupa penyediaan sarana dan prasarana serta penunjangnya. Pengoperasiannya berdasarkan satu sistem pengoperasian tertentu dan pasti, produk akhirnya berupa jasa yang mendatangkan manfaat bagi penerimanya secara langsung dan habis terpakai dalam jangka waktu tertentu. Contoh jenis pelayanan ini adalah : pelayanan angkutan darat, laut,

12 Ida Dwimawanti, "Kualitas Pelayanan Publik," Jurnal Ilmu Administrasi Dan Kebijakan Publik, 2004, 112.

${ }^{13}$ Dwimawanti, 112. dan udara, pelayanan kesehatan, pelayanan perbankan, pelayanan pos, dan pelayanan pemadaman kebakaran. (Kep. MENPAN No. 58/ KEP/M. PAN/9/2002). ${ }^{14}$

\section{Dimensi Pelayanan Publik}

Dalam hal kualitas pelayanan publik ada dua aspek pokok yang perlu diperhatikan, yakni: Pertama, aspek proses internal organisasi birokrasi (pelayanan); Kedua, aspek eksternal organisasi yakni kemanfaatan yang dirasakan oleh masyarakat pelanggan. Dalam hal ini Irfan Islamy (1999) menyebut beberapa prinsip pokok yang harus dipahami oleh aparat birokrasi publik dalam aspek internal organisasi yaitu: 1) Prinsip Aksestabelitas, dimana setiap jenis pelayanan (misal: masalah tempat, jarak dan prosedur pelayanan), 2) Prinsip Kontinuitas, yaitu bahwa setiap jenis pelayanan harus secara terus menerus tersedia bagi masyarakat dengan kepastian dan kejelasan ketentuan yang berlaku bagi proses pelayanan tersebut, 3) Prinsip teknikalitas, yaitu bahwa setiap jenis pelayanan proses pelayanannya harus ditangani oleh aparat yang benar-benar memahami secara teknis pelayanan tersebut berdasarkan kejelasan, ketepatan dan kemantapan sistem, prosedur dan instrumen pelayanan, 4) Prinsip profitabelitas, yaitu bahwa proses pelayanan pada akhirnya harus dapat dilaksanakan secara efektif dan efisien serta memberikan keun-

\footnotetext{
${ }^{14}$ Dwimawanti, 112.
} 
tungan ekonomis dan sosial baik bagi pemerintah maupun bagi masyarakat luas, 5) Prinsip Akuntabilitas, yaitu bahwa proses, produk dan mutu. ${ }^{15}$

\section{Konsep Pelayanan dalam Islam}

Menurut Kotler pelayanan merupakan sesuatu yang tidak berwujud berupa tindakan atau unjuk kerja yang ditawarkan oleh salah satu pihak ke pihak lain dan tidak menyebabkan perpindahan kepemilikan apapun. ${ }^{16}$ Sementara menurut Lovelock pelayanan adalah sebagai proses daripada prosuk, yaitu suatu proses yang melibatkan input dan mentransformasikan sebagai output. ${ }^{17}$ Pelayanan merupakan suatu cipta rasa yang menyenangkan yang diterima oleh konsumen yang disertai dengan sikap ramah dan kemudahan dalam menjangkau dan memenuhi kebutuhannya. Pelayanan diberikan sebagai suatu sikap dan tindakan perusahaan atau perorangan untuk memberkan rasa kepuasan kepada costumer atau pelanggan. Tidak dapat dipungkiri hampir disemua produk yang ditawarkan disetiap perusahaan memerlukan pelayanan yang baik, baik secara langsung maupun tidak langsung.

Dalam prakteknya konsumen memerlukan bantuan pelayanan untuk memenuhi

15 Ismet Sulila, Implementasi Dimensi Pelayanan Publik Dalam Konteks Otonomi Daerah, (Yogyakarta: DEEPUBLISH, 2015), 91

16 Philip Kotler, Manajemen Pemasaran: Analisis Perencanaan dan Implementasi dan Kontrol, Jilid I, (Jakarta, Erlangga, 2001), h. 83

17 Arief Muhtosim, Pemasaran Jasa dan Kualitas Pelayanan, (Malang: Bayumedia Publishing, 2007), hal. 11 kepuasan kebutuhannya, dan ini terbagi atas 4 (empat) macam, yaitu ${ }^{18}$ :

1. Nasabah memerlukan bantuan seseorang (customer service, pramuniaga atau kasir) untuk menuntun atau memperoleh informasi tentang segala hal yang berkaitan dengan produk. mulai dari mencari produk yang diinginkan, memilih produk, meminta penjelasan tantang produk sampai dengan pembayaran di kasir.

2. Nasabah memerlukan hanya ketika saat ada keperluan saja atau seperlunya, artinya nasabah datang lalu mencari hal yang diperlukan lalu memilih sendiri dan berakhir bertemu dengan petugas pada saat melakukan pembayaran.

3. Nasabah membutuhkan dengan melalui telepon, dalam hal ini pelanggan tidak bertatap muka langsung dengan karyawan tetapi berbicara melalui suara.

4. Nasabah tidak perlu meminta bantuan petugas jika tidak dalam keadaan penting, artinya yang dihadapi nasabah dalam hal ini adalah mesin.

Menurut Pasuraman terdapat lima dimensi pelayanan, yaitu : ${ }^{19}$

1. Berwujud (tangible) yaitu kemampuan suatu perusahaan dalam menunjukkan eksistensinya

18 Philip Kotler, Manajemen Pemasaran : Analisis Perencanaan dan Implementasi dan Kontrol, Jilid 1, ( Jakarta, Erlangga, 2001),h.83

${ }^{19}$ Rambat Lupiyadi dan A.Hamdana, Manajemen Pemasaran Jasa,( Jakarta : Salemba Empat, 2009), h.182 
kepada pihak eksternal. Penampilan dan kemampuan sarana dan prasarana fisik perusahaan yang dapat diandalkan keadaan lingkungan

sekitarnya merupakan bukti nyata dari pelayanan yang diberikan oleh pemberi jasa. Hal ini meliputi ruang tunggu pelayanan, perlengkapan yang digunakan dan Penampilan Petugas Pelayanan.

2. Keandalan (reliability) yaitu kemampuan perusahaan untuk memberikan pelayanan sesuai dengan yang dijanjikan secara akurat dan terpercaya. Kinerja harus sesuai dengan harapan pelanggan, Keandalan petugas dalam memberikan informasi pelayanan, Keadalan petugas dalam melancarkan prosedur pelayanan, dan Keadalanan petugas dalam memudahkan teknis pelayanan.
3. Ketanggapan (responsiviness) yaitu suatu kebijakan untuk membantu dan memberikan pelayanan yang cepat dan tepat kepada pelanggan dengan penyampaian informasi.

4. Jaminan dan Kepastian (assurance) yaitu pengetahuan, kesopan santunan dan kemampuan para pegawai perusahaan untuk menumbuhkan rasa percaya para pelanggan.

\section{SIMPULAN}

Sebagai perusahaan yang baik, harus selalu mengedepankan profesionalisme dalam melayani nasabah dengan sesuai bidang dan tanggungjawabnya serta mengacu kepada pedoman dalam setiap proses pelayanannya. Dalam mewujudkan pelayanan nasabah yang berkwalitas, maka dalam setiap unit pelayanan harus sesuai dengan standar pelayanan minimal (cheaper, better, faster).

\section{DAFTAR PUSTAKA}

Amylia Fakhira, Jurnal Peayanan Publik Dalam Hukum Administrasi Negara

Barata Adya, Atep, Dasar-Dasar Pelayanan Prima. (Jakarta:PT Elex Media Komputindo, 2004)

Ida Dwimawanti, "Kualitas Pelayanan Publik," Jurnal Ilmu Administrasi Dan Kebijakan Publik, 2004, 112.

Pasolong Harbani, Teori Administrasi Publik, (Bandung: Alfabeta, 2011), 128.

Sulila Ismet, Implementasi Dimensi Pelayanan Publik Dalam Konteks Otonomi Daerah, (Yogyakarta: DEEPUBLISH, 2015), hlm. 73-74

Tuasikal Hadi, Jurnal Membedah Konsep Pelayanan Publik Dan Good Governance Dalam Perspektif Hukum Administrasi,

Ustman Muhammad Ali, Figh al Muamalah: Dirasah Muqaranah (Riyadh: Dār al Mirikh, 1986), hlm. 352-390

Zeithaml, V.A., Parasuraman \& L.L. Berry, Delivering Quality Services, 1990. 
dicky maulidhany 